\title{
An Investigation into the Interest Elasticity of Demand for Money in Developing Countries: A Panel Data Approach
}

\author{
Felix S. Nyumuah ${ }^{1}$ \\ ${ }^{1}$ Department of Financial Management, Zenith University College, Accra, Ghana \\ Correspondence: Felix S. Nyumuah, P.O. Box SK 237, Sakumono Estates, Tema, Ghana. Tel: 233-243-671-295. \\ E-mail: fsnyumuah@yahoo.co.uk or silverglw7@gmail.com
}

Received: December 19, 2016

Accepted: January 17, $2017 \quad$ Online Published: February 15, 2017

doi:10.5539/ijef.v9n3p69

URL: https://doi.org/10.5539/ijef.v9n3p69

\begin{abstract}
The issue as to whether the interest rate influences the demand for money in developing countries is still controversial. The aim of this study is to attempt to resolve this controversy. The study uses panel data from eight African countries to look at the interest elasticity of demand for money in developing countries. The countries used in the study are Angola (ANG), Equatorial Guinea (EQG), Gambia (GMB), Guinea-Bissau (GBS), Kenya (KNY), Mali (MLI), Nigeria (NGR) and Uganda (UGD). Overall, the study finds the interest rate to be inelastic in the short run but elastic in the long run. This finding suggests that monetary policy is ineffective in developing countries in the long run.
\end{abstract}

Keywords: demand for money, interest rates effects, monetary policy, panel data models

\section{Introduction}

Researchers have conducted a lot of studies into the demand for money over the past decades. This is because understanding the demand for money in an economy is key to the formulation and implementation of monetary policy. The success of monetary policy depends on the degree of responsiveness of money demand to the interest rate. Researchers have often argued that the interest rate does not play a significant role in determining the demand for money in developing countries because of the dearth of financial assets. The issue of whether the interest rate influences the demand for money in developing countries is still controversial in the light of mixed results obtained so far by researchers. For instance, the domestic interest rate is found to play a statistically significant role in explaining the long-run demand for M1 balances in some developing countries whilst the expected inflation rate shows a short-run impact in others (Simmons, 1992). Arize and Nam (2012) find the domestic interest rates to have significant negative effects on the demand for money for seven Asian countries. Econometric analysis of the demand for money from some earlier studies have found the interest rate to be statistically insignificant (Terriba, 1973, Pathak, 1981). In addition to this controversy about the interest rate, the use of more advanced statistical techniques in modelling demand for money is gaining popularity among researchers. The purpose of this study is to use panel data techniques to resolve the controversy surrounding the interest elasticity of demand for money in developing countries.

This paper computes the short and long run interest rate elasticity for a panel of eight sub-Saharan African countries and argues that the interest rate is inelastic in the short run but elastic in the long run. Based on the IS-LM framework, the study concludes that the economies of these countries will be in the Keynesian range in the long run. Policymakers cannot safely rely on monetary policy to influence output and inflation in the long run.

I obtain the interest elasticity coefficients of the money demand function by using a panel Fully Modified Ordinary Least Squares (FMOLS) estimations for the long run and the estimates of fixed and random effects error correction models for the short run. Panel unit root tests initially carried out show that all the variables under study are integrated of order one. Pedroni cointegration tests also indicate that cointegration exists. The Fully Modified Ordinary Least Squares estimates of the money demand function show that the interest rate exerts a significant influence on the demand for money whilst the expected rate of inflation does not play a significant role in explaining money demand in the long run. However, the error correction model representing the short run dynamics of the money demand shows that the expected rate of inflation is statistically significant and the interest rate is statistically insignificant in the short run. 
The literature which examines the demand for money in developing countries, using panel data techniques and incorporating modern time series methods (e.g., Harb, 2004; Carrera, 2008; Hamori, 2008; Valadkhani, 2008; Rao \& Kumar, 2009), influences the conduct of this study. All the studies except Hamori (2008) were conducted for Asian countries. Hamori (2008) used Pedroni Fully Modified Ordinary Least Squares (FMOLS) to analyse the money demand function for Sub-Saharan Africa. The interest rate was significant with the correct negative sign. Also, all the studies but Valadkhani (2008) estimated only a long run money demand function. Valadkhani (2008) examined both the long run and short run determinants of money demand for six Asian-Pacific countries. From the literature, there has been no study from Africa analysing both the long run and short run money demand function within a panel framework. This study contributes to the literature in that, unlike the earlier studies, it focuses on the issue of the interest rate influence on the money demand function in developing countries by using data from Sub-Saharan African countries, and at the same time demonstrates by using a panel FMOLS and an error correction model that the interest rate is inelastic in the short run but elastic in the long run. This is because economic agents are not able to substitute money for financial assets as the interest rate rises. However, in the long run, they are able to find more financial assets and adjust to equilibrium. Generating results from Africa in this way provides more evidence to support the theory of demand for money for developing countries. This study uses data from eight Sub-Saharan African countries. I chose these countries because consistent time series data on all the variables included in the model were available.

The paper continues with Section 2 reviewing the theoretical literature of money demand and providing evidence to show the controversial nature of interest elasticity of money demand in developing countries. This section discusses the relationship between interest elasticity of demand for money and monetary policy. It demonstrates that the more interest elastic the demand for money the less effective monetary policy is. Section 3 reviews the advantages of panel data over pure cross sectional or time series data and specifies the fixed effects and random effects models. It shows that panel data leads to efficiency in econometric estimates and improvement in statistical inference. Section 4 describes the estimation techniques, estimates and interprets the results. Section 5 discusses policy implications and directions for future research.

\section{A Review of Literature}

This section reviews the theoretical underpinnings of the demand for money and the empirical evidence from past researchers concerning the right opportunity cost variable in the money demand function of developing countries. It further examines the effectiveness of monetary and fiscal policies using the IS-LM framework.

\subsection{The Theoretical Literature}

Fisher (1911) came out with the classical quantity theory which was the earliest attempt to formulate a theory of demand for money. The classical quantity theory is expressed as an equation of exchange where the total money supply determines the total amount of spending on final goods and services. Fisher assumes money is held only for transaction purposes. With money market equilibrium, the supply of money is equal to the demand for money, and the equation can be transformed into a money demand function where the amount of cash balances held is purely a function of nominal income. Thus the interest rate plays no role in determining the demand for money in this formulation.

As an improvement over Fisher's theory, Pigou (1917) and Marshal (1923) developed the Cash Balance version of the Quantity Theory. These neoclassical economists explicitly express the equation as a money demand function showing the amount of cash balances held as a function of nominal income. They consider the possible influence of wealth and the interest rate in the function through their influence on the velocity of circulation.

Keynes (1936), in his liquidity preference theory, showed that the amount of money held is inversely related to the interest rate. Keynes distinguished between real and nominal values. According to Keynes, the interest rate, which influences money demand appreciably, and real income determine the demand for real cash balances. To further develop the Keynesian theory, Baumol (1952) and Tobin (1956) showed that the transactions demand for money was also sensitive to the interest rate. Their optimum inventory analysis leads to the square root formula which expresses optimal demand for real balances as a function of transaction costs, level of transactions and the interest rate. Tobin (1958) explains the demand for money as aversion to risk. He argues that the individual will diversify his portfolio by holding some proportion of wealth in money because doing so lowers the overall riskiness of the portfolio. Given a person's degree of risk aversion, a higher expected return (nominal interest rate plus expected capital gains on bonds) will cause agents to shift away from safe money and into risky assets. This creates a negative relationship between the nominal interest rate and the demand for money. Friedman (1956) refines the classical Quantity Theory and treats the demand for money like the demand for any other asset. Wealth, according to Milton Friedman, can be held in the form of money, bonds, equity and real assets. The 
demand for money is specified as a function of permanent income and expected returns relative to the expected return on money. The demand for money is positively related to permanent income and inversely related to the expected returns on the various assets relative to the expected return on money. Since real assets are considered a form of holding wealth, the expected rate of inflation relative to the expected return on money is introduced as a variable in the money demand function. Friedman, however, predicts a weak negative correlation between money demand and interest rates.

The standard demand for money theories assume well-developed financial markets exist with financial assets readily available. However, financial markets in developing countries are undeveloped. The interest rate is often considered as an unsatisfactory measure of the opportunity cost of holding money, because the dearth of financial assets limits the substitution between money and financial assets. The expected rate of inflation is regarded a more appropriate measure, because of the likelihood to substitute physical assets for money in developing countries.

\subsection{Empirical Evidence from Developing Countries}

As is obvious from the previous section it is believed that the expected rate of inflation and not the interest rate should be the appropriate opportunity cost variable in the money demand function for developing countries. Several studies have used the inflation rate as the opportunity cost of holding money; (for instance, Wong, 1977; Suliman \& Dafaalla, 2011; Bahmani-Oskooee \& Bahmani, 2015). Further explanation given in favour of the expected rate of inflation is that interest rates are regulated by the government and remain unchanged for long periods of time. For these reasons, it is more appropriate to use the inflation rate as a proxy for the opportunity cost of holding money (Tang, 2009; Bahmani, 2013). Laidler (1985) justifies the inclusion of the nominal interest rate as own rate of money as well as the expected inflation rate. Arestis and Demetriades (1991) argues for the inclusion of both variables since nominal interest rates can be considered as own-rate of money; and the expected inflation rate is the return on real assets. Thus studies like Rao and Kumar (2010) and Abdulkheir (2013) have included both the interest rate and the inflation rate in the money demand function.

Studies that have been carried out have used both single countries and panels of countries. For instance, Rao and Singh (2005) in a study of the demand for money in India using unit roots and cointegration methodology, showed that the interest elasticity of the demand for $M 1$ is significant. Using a partial adjustment method (PAM), Hossain (2006) found the interest rate to be statistically significant in the money demand function for Bangladesh. Rao and Kumar (2007), using time series approach and the Gregory and Hansen technique for structural breaks to estimate the demand for real narrow money for Bangladesh for the period 1973-2003, found the interest rate elasticity to be significant and negative. Baharumshah, Mohd, and Masih (2009) also looked at the demand for money in China. In the preliminary analysis, they found that the domestic interest rate elasticity was insignificant even at the $10 \%$ significance level. This result could be due to the fact that interest rates remained heavily administered. Kumar, Webber and Fargher (2010) estimated the demand for real narrow money (MI) for Nigeria over the period 1960-2008.They found the interest rate elasticity to be negative and significant. Dagher and Kovanen (2011) in a study of the demand for money for Ghana found the interest rate to be statistically insignificant. Some other studies (like Herve \& Shen, 2011; Sichei \& Kamau, 2012), carried out on single country basis, have found the interest rate to impact negatively on money demand.

Concerning panels of countries, Simmons (1992) used an error-correction model to examine the demand for money for a panel of five African countries comprising the Democratic Republic of Congo, Ivory Coast, Mauritius, Morocco and Tunisia. The empirical results indicate that the domestic interest rate influences the demand for money significantly in the long run in the case of Ivory Coast, Mauritius and Morocco. He also found that inflation exerted a significant influence on money demand in four of the countries. Singh and Kumar (2012) using alternative time series techniques for 12 developing countries found for almost all the sample countries that, the interest elasticities were well determined and significant. Abdullah, Ali, and Matahir (2010) reexamined the demand for money in Singapore, Malaysia, Thailand, Indonesia, and the Philippines. The inflation elasticity was negative. Narayan, P. K., Narayan, S., and Mishra (2009) estimated a money demand function for a panel of five South Asian countries. The impact of the short-term domestic nominal interest rate produced mixed results. For Bangladesh and India, the interest rate was negative and statistically significant. However, the interest rate was negative but statistically insignificant for Sri Lanka. On the other hand, for Pakistan and Nepal, the relationship while positive was statistically insignificant. Rao and Kumar (2009) estimated the cointegrating equations for the money demand of a panel of 14 Asian countries from1970-2005.The elasticity estimates were all significant at the 5\% level. The interest rate elasticity carried the anticipated negative sign. Some other studies which have applied panel data techniques in recent times are Kumar, Chowdhury, and Rao (2010) and Rao and Kumar (2010). Kumar et al. (2010) found money demand to 
respond negatively to the interest rate and Rao and Kumar (2010) found the nominal short-and-long-term interest rates and the rate of inflation as robust proxies of the opportunity cost of holding money. It appears mixed results have so far been obtained by various researchers regarding the relevant opportunity cost variable in money demand functions in developing countries.

\subsection{Interest Rate Elasticity and Monetary Policy}

Monetary policy and fiscal policy are two main policies used in the stabilisation of economies. Monetary policy is conducted by using the money supply or the interest rate as a policy instrument. A change in any of the policy instruments will be expected to affect inflation and output. According to the Keynesian transmission mechanism, money affects inflation and output indirectly through the interest rate. Expanding the money supply reduces interest rates; the cost of borrowing for firms and consumers. This leads to increased consumption as well as investment. There is therefore an increase in demand and a higher output gap resulting finally in higher prices and inflation. The lower the interest elasticity of money demand the more effective is monetary policy and the less effective is fiscal policy in regulating an economy. On the other hand, the higher the interest elasticity of money demand the less effective is monetary policy and the more effective is fiscal policy.

The relationship between interest elasticity and the effectiveness of monetary policy can be explained using the IS and LM framework. Suppose the monetary authority pursues an expansionary monetary policy by increasing the money supply. An increase in the money supply will shift the LM curve to the right. As shown in Figure 1, such a policy will be most effective if the money supply is increased when the IS curve intersects the LM curve in the classical range. Since here the demand for money is perfectly interest inelastic, an increase in the money supply will cause a significant reduction in the interest rate. This will, in turn, produce a large stimulative effect on investment. Consequently, income will rise. In Figure 1, when LM shifts from $\mathrm{LM}_{1}$ to $\mathrm{LM}_{2}$, the interest rate falls from $\mathrm{i}_{3}$ to $\mathrm{i}_{3}^{\mathrm{I}}$ and income rises from $\mathrm{Y}_{3}$ to $\mathrm{Y}_{3}{ }_{3}^{\mathrm{I}}$.

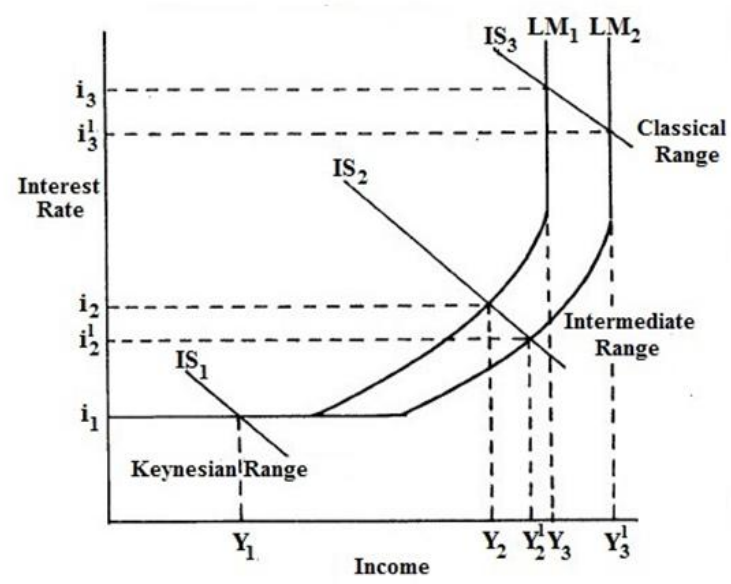

Figure 1. Effect of moneytary policy on income

If the money supply is increased when the IS curve intersects the LM curve in the intermediate range, the interest rate will fall from $\mathrm{i}_{2}$ to $\mathrm{i}_{2}^{\mathrm{I}}$. As a result, investment and, consequently, income will rise. Income will rise from $\mathrm{Y}_{2}$ to $\mathrm{Y}_{2}^{1}$. The interest rate falls because the increase in the money supply is only partially absorbed by the increase in the demand for idle cash balances. Monetary policy will therefore be partially effective in the intermediate range.

Monetary policy is completely ineffective in the Keynesian range. If the money supply is increased when the IS curve intersects the LM curve in the Keynesian range, the increase in the money supply will be fully absorbed by an increase in the demand for money (demand for idle cash balances). As a result, the interest rate will remain unchanged. If the interest rate does not decline, neither investment nor income will rise. Income will remain at $\mathrm{Y}_{1}$ level.

Concerning fiscal policy, Keynesians believe the effect depends upon the size of the shift and the slopes of both IS and LM curves. Suppose the fiscal authority pursues an expansionary policy by increasing government spending and uses bonds to finance it. An increase in government spending will shift the IS curve to the right. As shown in Figure 2, such a policy will be most effective if IS intersects LM in the Keynesian range (where LM is perfectly elastic); somewhat effective if it occurs in the intermediate range (where LM is somewhat elastic); and completely ineffective if it occurs in the classical range (where LM is vertical or perfectly inelastic). In the 
Keynesian range, such an action will be most effective because the shift of IS from $1 \mathrm{~S}_{1}$ to $\mathrm{IS}_{1}{ }_{1}$ does not increase the interest rate, thereby causing no adverse effect on private investment. However, in the classical range, similar action causes such an increase in the interest rate that private investment equal to the increase in government spending is crowded out. In the figure, when the shift occurs from $\mathrm{IS}_{3}$ to $\mathrm{IS}_{3}^{1}$ the interest rate rises from $\mathrm{i}_{3}$ to $\mathrm{i}_{3}^{1}$. But income stays at the same level, i.e., $\mathrm{Y}_{3}$. The interest rate rises because the increase in government spending causes an increase in its borrowing from the market.

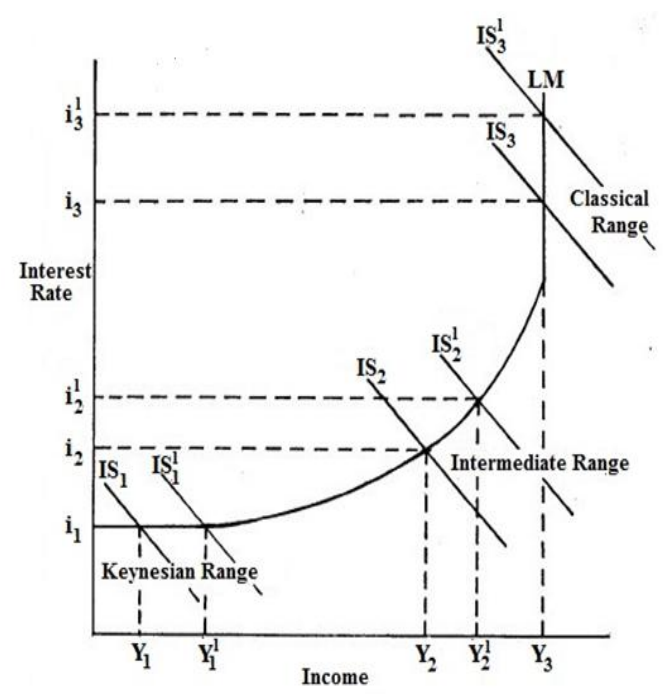

Figure 2. Effect of fiscal policy on income

In the case of the intermediate range, similar action is somewhat effective because only a part of its effect is counterbalanced by a fall in private investment. In Figure 2, when a shift occurs from $\mathbf{I S}_{2} \mathbf{I S}_{2}^{1}$, the interest rate rises from $i_{2}$ to $i_{2}^{1}$ and income, from $Y_{2}$ to $Y_{2}^{1}$. Thus, the effect of fiscal action depends, among other things, upon the slope of the LM curve. The steeper the LM curve, the less will be its effect. Keynesians claim that there is overwhelming evidence that the short run LM curve is not vertical: the demand for money is negatively related to the interest rate.

To sum up, monetary policy is more potent in stabilising the economy when the demand for money is interest inelastic, whilst fiscal policy will be a more effective tool when the demand for money is interest elastic.

\section{Money Demand Models and Advantages of Panel Data}

This section discusses the benefits to be derived from using panel data instead of pure time series or cross sectional data. It also specifies the fixed effects and random effects models of the money demand function.

\subsection{Advantages of Panel Data}

Panel or longitudinal data set comprises time-series observations over cross-sectional units like countries, firms and randomly-sampled individuals. It is either a balanced panel with the same time periods or unbalanced panel with time dimension specific to each cross-sectional unit. Panel data sets have several benefits as compared to pure time-series or cross-sectional data sets (Gujarati, 2003, pp. 638-640). Panel data ensures much larger data which increases the degrees of freedom. There is more variability and less collinearity among the explanatory variables which improve the efficiency of econometric estimates. It captures individual heterogeneity, that is unobserved individual specific effects, leading to more reliable estimates. Panel data is good for uncovering complex issues of dynamic behaviour. Economic behaviour is inherently dynamic. Koyck or Almon distributed lag models involving current and lagged variables which are highly collinear are often used. The use of panel data captures inter-individual differences which reduces the collinearity between the current and lagged variables. Panel data sometimes simplifies statistical computation and inference. With non-stationary time series, the large sample approximation distribution will not hold for the least squares and maximum likelihood estimators. However, with independent observations across cross-sectional units one can invoke the Central Limit Theorem and estimators will become asymptotically normal (Phillips \& Moon, 1999, 2000; Quah, 1994). Panel data analysis involves the use of fixed effects and random effects models which are discussed below.

\subsection{The Fixed Effects Model}

If money is regarded as one of several assets in a portfolio, a conventional demand for money function in 
logarithmic form is specified as follows:

$$
\operatorname{Inm}_{t}=\beta_{0}+\beta_{I} \operatorname{In} Y_{t}+\beta_{2} \operatorname{In} R_{t}+\beta_{3} \operatorname{In} \Pi_{t}+\varepsilon_{t}
$$

where $\mathrm{m}_{\mathrm{t}}$ is real narrow money balances. $\mathrm{Y}_{\mathrm{t}}$ is the real GDP; $\mathrm{R}_{\mathrm{t}}$ is the interest rate variable; $\Pi_{\mathrm{t}}$ is the inflation rate variable; and the stochastic disturbance is $\varepsilon_{t}$. To avoid negatives the consumer price index is used as a proxy for the inflation rate. Real money balances are assumed to be positively related to real income; that is, $\beta_{1}$ is expected to be positive. On the other hand, the interest rate $\left(\mathrm{R}_{\mathrm{t}}\right)$ is expected to be negatively related to money demand so that $\beta_{2}$ carries a negative sign. Similarly, the expected inflation rate $\left(\pi_{t}\right)$ is anticipated to be negatively related to money demand, so $\beta_{3}$ is expected to be negative.

Pooling, or combining all the 120 observations for the eight African countries for the period 1980 to 2012, we can rewrite the money demand function as:

$$
\operatorname{Inm}_{i t}=\beta_{0}+\beta_{1} \operatorname{In} Y_{i t}+\beta_{2} \operatorname{InR} R_{i t}+\beta_{3} \operatorname{In} \Pi_{i t}+\varepsilon_{i t} ; i=1,2,3,4,5,6,7,8 \text { and } t=1,2, \ldots 15
$$

where $i$ stands for the $i$ th cross-sectional unit and $t$ for the $t$ th time period.

There are differences in the eight African countries in terms of socio-economic development. Estimating model (2) without taking into account the individual country heterogeneity will lead to omitted variable bias. If the country-specific effect is correlated with the independent variables a way to allow for the unobserved specific effects of each country is to let the intercept vary for each country but still assume that the slope coefficients are constant across nations. To see this, model (2) is written as:

$$
\operatorname{Inm}_{i t}=\beta_{0 i}+\beta_{1} \operatorname{In} Y_{i t}+\beta_{2} \operatorname{In} R_{i t}+\beta_{3} \operatorname{In} \Pi_{i t}+\varepsilon_{i t}
$$

This is known as the fixed effects model. The subscript $i$ is put on the intercept term to suggest that the intercepts of the eight countries may be different. the differences may result from differences in characteristics of each country, such as human development or degree of industrialization. Obviously the use of a fixed effects model such as Equation (3) will lead to more accurate results as it takes into account individual country heterogeneity.

\subsection{The Random Effects Model}

If the country-specific effect is uncorrelated with the regressors a way of capturing individual heterogeneity is to use the random effects model.

The basic idea is to start with (3):

$$
\operatorname{Inm}_{i t}=\beta_{0 i}+\beta_{1} \operatorname{In} Y_{i t}+\beta_{2} \operatorname{In} R_{i t}+\beta_{3} \operatorname{In} \Pi_{i t}+\varepsilon_{i t}
$$

Instead of treating $\beta_{0 i}$ as fixed, we assume that it is a random variable with a mean value of $\beta_{0}$ (no subscript $i$ here). The intercept value for an individual country can be expressed as

$$
B_{0 i}=\beta_{0}+v_{i} \quad i=1,2, \ldots, N
$$

where $v_{i}$ is a random error term with a mean value of zero and variance of $\sigma_{v}{ }^{2}$.

Basically, the eight countries included in the sample are a drawing from a much larger universe of such countries. The mean values of the intercept $\left(=\beta_{0}\right)$ are the same for all the countries and the individual differences in the intercept values of each country are reflected in the error term $v_{i}$.

I substitute (4) into (3), to get:

$$
\begin{aligned}
\operatorname{Inm}_{i t} & =\beta_{0}+\beta_{1} \operatorname{In} Y_{i t}+\beta_{2} \operatorname{InR}_{i t}+\beta_{3} \operatorname{In} \Pi_{i t}+v_{i}+\varepsilon_{i t} \\
& =\beta_{0}+\beta_{1} \operatorname{In} Y_{i t}+\beta_{2} \operatorname{In} R_{i t}+\beta_{3} \operatorname{In} \Pi_{i t}+w_{i t}
\end{aligned}
$$

where $w_{i t}=v_{i}+\varepsilon_{i t}$

The composite error term $w_{i t}$ consists of two components, $v_{i}$, the cross-section error component, and $\varepsilon_{\mathrm{it}}$, which is the combined time series and cross-section error component. Equation (5) is the random effects model. Its estimation, like the fixed effects model, will yield more reliable results. Thus, fixed and random effects error correction models are used in the study.

\section{Empirical Methods and Results}

This section describes the empirical estimation methods and presents the results. This research work basically involves the use of panel data to examine interest elasticity of demand for money in developing countries. The research tools used consist of panel unit root tests, cointegration tests, error correction models with fixed and random effects, and the panel Fully Modified Ordinary Least Squares (FMOLS) estimation technique. Panel unit roots tests were carried out prior to cointegration analysis. Having established cointegration among the variables, an error correction mechanism was used to capture the short run dynamics. Finally, the panel Fully Modified 
Ordinary Least Squares method was used to estimate the long run money demand function. Money demand for developing countries was found to be interest inelastic in the short run but interest elastic in the long run.

\subsection{Empirical Tests and Estimation Methods}

Before undertaking any regression analysis, the time series properties of the data are examined. There is the need to ensure that all the variables are stationary in order to avoid the problem of spurious regression caused by non-stationary variables. In doing so, I used the panel-based unit root tests developed by Levin, Lin, and Chu (2002), Breitung (2000), Hadri (1999), and Im, Pesaran and Shin (2003). These researchers have shown that panel unit root tests are more powerful than unit root tests applied to pure time series because the information in the time series is augmented by that contained in the cross-section data. The computations of the test statistics were done with EViews econometric software.

Having established that all the variables are integrated of the same order, I followed the methodology used by Pedroni (1999) to test for cointegration. This method uses four panel statistics and three group panel statistics to test the null hypothesis of no cointegration against the alternative hypothesis of cointegration. If the null hypothesis is rejected in the case of the panel, then the variables of the money demand function are cointegrated for all the countries. However, if the null hypothesis is rejected in the case of the group panel, then cointegration exists among the relevant variables for at least one of the countries. Pedroni Residual Cointegration tests in cases with no deterministic trend and with deterministic intercepts and trend were carried out with EViews.

Cointegration is established among the variables which means an error correction model can be run. This is a representation of the short run demand for money. In this representation, short-run dynamics are captured by estimating in first differences. Adjustments in reaction to the deviation of real money demand from the long-term level are captured by including the equilibrium correction term. The error correction model was estimated for both fixed and random effects with EViews. Finally, I used the panel fully modified OLS estimator (FMOLS) to examine the long run money demand function because the Ordinary Least Squares (OLS) estimator is biased and inconsistent when applied to cointegrated panels. Following Kao, Chiang, and Chen (1999) the estimations were carried out in EViews.

\subsection{Results}

The panel data consists of eight African countries $(N=1 \ldots .8)$ for the period 1998 to $2012(T=1 \ldots . .15)$. The selected countries are Angola (ANG), Equatorial Guinea (EQG), Gambia (GMB), Guinea-Bissau (GBS), Kenya (KNY), Mali (MLI), Nigeria (NGR), Uganda (UGD). The data is extracted from World Bank Development Indicators 2003. The data used are the logarithmic values of the variables concerned. The results of the panel unit root tests under the $\mathrm{H}_{0}$ of Non-stationarity (Note: in the case of the Hadri test the null is that the variable is stationary.) are displayed in Table 1.

Table 1. Panel unit root tests 1998-2012

\begin{tabular}{lcccccc}
\hline Series & LLC & Breitung-t & IPS-W & ADF & PP & Hadri \\
\hline \multirow{2}{*}{$\operatorname{In}(\mathrm{m})$} & -4.1589 & 0.38975 & -0.2953 & 19.2893 & 27.2491 & 5.8906 \\
& $(0.0000)$ & $(0.6516)$ & $(0.3839)$ & $(0.2539)$ & $(0.0388)$ & $(0.0000)$ \\
$\operatorname{In}(\mathrm{Y})$ & -2.94841 & -0.90186 & -0.30913 & 16.4388 & 17.0316 & 6.04726 \\
& $(0.0016)$ & $(0.1836)$ & $(0.3786)$ & $(0.4228)$ & $(0.3836)$ & $(0.0000)$ \\
$\operatorname{In}(\mathrm{R})$ & -2.83391 & 0.59473 & -0.45167 & 12.6099 & 12.8735 & 4.33513 \\
& $(0.0023)$ & $(0.7240)$ & $(0.3258)$ & $(0.3980)$ & $(0.3783)$ & $(0.0000)$ \\
$\operatorname{In}(\Pi)$ & -4.76198 & 4.63555 & -1.13218 & 24.8534 & 18.8992 & 6.47793 \\
& $(0.0000)$ & $(1.0000)$ & $(0.1288)$ & $(0.0725)$ & $(0.2739)$ & $(0.0000)$ \\
$\Delta \operatorname{In}(\mathrm{m})$ & -8.55875 & -1.36149 & -5.19219 & 53.4355 & 64.6709 & 5.9878 \\
& $(0.0000)$ & $(0.0867)$ & $(0.0000)$ & $(0.0000)$ & $(0.0000)$ & $(0.0000)$ \\
$\Delta \operatorname{In}(\mathrm{Y})$ & -4.41507 & -2.85344 & -3.19827 & 37.2922 & 63.2121 & 5.69993 \\
& $(0.0000)$ & $(0.0022)$ & $(0.0007)$ & $(0.0019)$ & $(0.0000)$ & $(0.0000)$ \\
$\Delta \operatorname{In}(\mathrm{R})$ & -5.85557 & -2.27119 & -3.00053 & 29.3306 & 48.3146 & 3.81265 \\
& $(0.0000)$ & $(0.0116)$ & $(0.0013)$ & $(0.0035)$ & $(0.0000)$ & $(0.0001)$ \\
$\Delta \operatorname{In}(\Pi)$ & -6.22078 & -2.09465 & -3.94871 & 44.9151 & 54.0124 & 5.88945 \\
& $(0.0000)$ & $(0.0181)$ & $(0.0000)$ & $(0.0001)$ & $(0.0000)$ & $(0.0000)$ \\
\hline
\end{tabular}

Note. The tests are: Levin, Lin and Chu (2002, LLC), Breitung (2000), Im, Pesaran and Shin (2003, IPS), ADF Fisher (ADF), PP Fisher (PP), and Hadri (1999). The probability values are reported in parentheses. 
These tests give somewhat mixed results. With the exception of the LLC and PP tests all the other tests confirm that $\operatorname{In}(\mathrm{m})$ is non-stationary and all the other tests apart from the LLC test indicate that $\operatorname{In}(\mathrm{Y})$ is non-stationary at the 5\% level of significance. Also, all tests apart from the LLC test confirm that $\operatorname{In}(\mathrm{R})$ and $\operatorname{In}(\Pi)$ are non-stationary at the 5\% level of significance. Most of the tests indicate that the first differences of these variables are stationary and so one can conclude that the variables are I(1) in their levels.

Tables 2 and 3 show results for Pedroni Residual Cointegration between the three variables in equation (1) in cases with no deterministic trend and with deterministic intercepts and trend under the $\mathrm{H}_{0}$ of No cointegration. The majority of the reported tests show that there is cointegration between these variables at the $5 \%$ level.

Table 2. Pedroni residual cointegration tests

\begin{tabular}{llc}
\hline & \multicolumn{2}{c}{ No deterministic trend } \\
\cline { 2 - 3 } Test Statistics & Statistics & Weighted Statistics \\
\hline \multirow{2}{*}{ Panel v-Statistic } & -0.43828 & -0.51533 \\
Panel rho-Statistic & $(0.6694)$ & $(0.6968)$ \\
& 0.317002 & 0.202557 \\
Panel PP-Statistic & $(0.6244)$ & $(0.5803)$ \\
& -3.19433 & -3.29877 \\
Panel ADF-Statistic & $(0.0007)$ & $(0.0005)$ \\
& -2.73709 & -3.81356 \\
Group rho-Statistic & $(0.0031)$ & $(0.0001)$ \\
Group PP-Statistic & 1.262764 & \\
Group ADF-Statistic & $(0.8967)$ & \\
\hline
\end{tabular}

Note. The probability values are reported in parenthesis.

Table 3. Pedroni residual cointegration tests

\begin{tabular}{|c|c|c|}
\hline \multirow[b]{2}{*}{ Test Statistics } & \multicolumn{2}{|c|}{ Deterministic intercepts and trend } \\
\hline & Statistics & Weighted Statistics \\
\hline \multirow{2}{*}{ Panel v-Statistic } & -1.73902 & -1.82341 \\
\hline & $(0.9590)$ & $(0.9659)$ \\
\hline \multirow{2}{*}{ Panel rho-Statistic } & 1.026154 & 1.319513 \\
\hline & $(0.8476)$ & $(0.9065)$ \\
\hline \multirow{2}{*}{ Panel PP-Statistic } & -5.01552 & -3.68232 \\
\hline & $(0.0000)$ & $(0.0001)$ \\
\hline \multirow{2}{*}{ Panel ADF-Statistic } & -2.69266 & -2.05317 \\
\hline & $(0.0035)$ & $(0.0200)$ \\
\hline \multirow{2}{*}{ Group rho-Statistic } & 2.261932 & \\
\hline & $(0.9881)$ & \\
\hline \multirow{2}{*}{ Group PP-Statistic } & -4.89011 & \\
\hline & $(0.0000)$ & \\
\hline \multirow{2}{*}{ Group ADF-Statistic } & -3.17671 & \\
\hline & $(0.0007)$ & \\
\hline
\end{tabular}

Note. The probability values are reported in parenthesis.

Tables 4 and 5 give the estimated error correction model parameters, with the fixed and random effects respectively. These can be interpreted as the short run money demand functions. Changes in the interest rate is insignificant while changes in the expected rate of inflation is significant in both the fixed and random effects models at the 5\% level. It means the interest rate does not influence significantly the demand for money while the expected rate of inflation exerts a significant influence on money demand in the short run. The error correction term in the fixed effect model is statistically significant and negative. It indicates that agents adjust to equilibrium at the rate of $24 \%$ annually. The error correction term in the random effects model is also negative 
but insignificant with a speed of adjustment of $0.04 \%$ annually.

Table 4. Error correction model for the money demand with fixed effects

\begin{tabular}{lcccc}
\hline Variables & Coefficient & Std. Errors & t-Statistics & Prob. \\
\hline$\Delta \mathrm{In}\left(\mathrm{m}_{\mathrm{t}-1}\right)$ & -0.06403 & 0.089062 & -0.71894 & 0.4747 \\
$\Delta \mathrm{In}\left(\mathrm{Y}_{\mathrm{t}-1}\right)$ & 0.278095 & 0.279528 & 0.994875 & 0.3234 \\
$\Delta \mathrm{In}\left(\mathrm{R}_{\mathrm{t}-1}\right)$ & 0.056971 & 0.071929 & 0.79204 & 0.4311 \\
$\Delta \mathrm{In}\left(\Pi_{\mathrm{t}-1}\right)$ & -0.51387 & 0.189617 & -2.710048 & 0.0085 \\
$\mathrm{U}_{\mathrm{t}-1}$ & -0.24201 & 0.062592 & -3.866464 & 0.0003 \\
Constant & 0.342991 & 0.060088 & 5.70817 & 0.0000 \\
\hline R-squared & 0.650218 & Mean dependent var & 0.05701 & \\
Adjusted R-squared & 0.598012 & S.D. dependent var & 0.277258 & -0.50903 \\
S.E. of regression & 0.175789 & Akaike info criterion & -17668 & \\
Sum squared resid & 2.070412 & Schwarz criterion & -0.37598 & \\
Log likelihood & 30.85227 & Hannan-Quinn criter. & 1.814502 & \\
F-statistic & 12.45481 & Durbbin-Watson stat & & \\
Prob(F-statistic) & 0.0000 & & & \\
\hline
\end{tabular}

Table 5. Error correction model for the money demand with random effects

\begin{tabular}{lcccc}
\hline Variables & Coefficient & Std. Errors & t-Statistics & Prob. \\
\hline$\Delta \mathrm{In}\left(\mathrm{m}_{\mathrm{t}-1}\right)$ & 0.029066 & 0.084701 & 0.343159 & 0.7325 \\
$\Delta \mathrm{In}\left(\mathrm{Y}_{\mathrm{t}-1}\right)$ & 0.723468 & 0.257487 & 2.809723 & 0.0064 \\
$\Delta \mathrm{In}\left(\mathrm{R}_{\mathrm{t}-1}\right)$ & -0.00626 & 0.070116 & -0.0893 & 0.9291 \\
$\Delta \mathrm{In}\left(\Pi_{\mathrm{t}-1}\right)$ & -0.71288 & 0.12692 & -5.61678 & 0.0000 \\
$\mathrm{U}_{\mathrm{t}-1}$ & -0.00044 & 0.000911 & -0.48628 & 0.6282 \\
Constant & 0.106548 & 0.031227 & 3.412036 & 0.0011 \\
\hline R-squared & 0.528121 & Mean dependent var & 0.05701 & \\
Adjusted R-squared & 0.495351 & S.D. dependent var & 0.277258 & \\
S.E. of regression & 0.196961 & Sum squared resid & 2.793128 & \\
F-statistic & 16.11627 & Durbin-Watson stat & 2.000083 & \\
Prob(F-statistic) & 0.0000 & & & \\
\hline
\end{tabular}

Equation (1) estimates based on the Fully Modified Ordinary Least Squares (FMOLS) are presented in Table 6. The income elasticity is significant at the 5\% level and greater than unity. Both the rate of interest and the expected rate of inflation have negative signs, but while the interest rate is significant the expected rate of inflation is insignificant at the 5\% level. This indicates that whilst the interest plays a significant role in determining the demand for money in developing countries the expected rate of inflation does not.

Table 6. Panel Fully Modified Least Squares (FMOLS) for the money demand

\begin{tabular}{lccc}
\hline Variables & Coefficient & Std. Errors & t-Statistics \\
\hline $\operatorname{In}\left(\mathrm{Y}_{\mathrm{t}}\right)$ & 2.47326 & 0.357701 & 6.914324 \\
$\mathrm{In}\left(\mathrm{R}_{\mathrm{t}}\right)$ & -0.319097 & 0.122697 & -2.600682 \\
$\mathrm{In}\left(\Pi_{\mathrm{t}}\right)$ & -0.444922 & 0.261601 & -1.700769 \\
\hline R-squared & -138.245418 & Mean dependent var & 16.2074 \\
Adjusted R-squared & -210.729334 & S.D. dependent var & 1.712992 \\
S.E. of regression & 24.92561 & Sum squared resid & 45353.88 \\
Long-run variance & 0.02415 & & 0.0930 \\
\hline
\end{tabular}

\section{Conclusion}

In the light of the controversy surrounding the role of the interest rate in money demand functions of developing countries, this study set out to investigate the interest elasticity of the money demand function in developing countries using panel data of eight African countries for the period 1998 to 2012. 
A review of the theoretical literature indicates that Fisher's postulation of the quantity theory was the earliest attempt to formulate a money demand theory. Fisher assumes money is held for only transaction purposes. With money market equilibrium, the supply of money is equal to the demand for money, and the equation can be transformed into a money demand function where the amount of cash balances held is purely a function of nominal income. According to Keynes, the interest rate, which influences money demand appreciably, and real income determine the demand for real cash balances. To further develop the Keynesian theory, Baumol (1952) and Tobin (1956) show that the transactions demand for money is also sensitive to the interest rate. Since real assets are considered a form of holding wealth the expected rate of inflation relative to the expected return on money is introduced as a variable in the money demand function.

Empirical evidence from developing countries to support the theory of money demand provides mixed results. For instance, Kumar, Webber, and Fargher (2010) estimated the demand for real narrow money (M1) for Nigeria over the period 1960-2008. They found the interest rate elasticity to be negative and significant whilst Dagher and Kovanen (2011) in a study of the demand for money for Ghana found the interest rate to be statistically insignificant.

The relationship between interest elasticity and the effectiveness of monetary policy is explained using the IS and LM framework. It is found that monetary policy is more potent in stabilising the economy when the demand for money is interest inelastic, whilst fiscal policy will be a more effective tool when the demand for money is interest elastic.

Panel data is used in the study as it has several benefits as compared to pure time-series or cross-sectional data sets. First, the study tests the panel variables for unit roots and shows that they exhibit a unit root. Pedroni cointegration tests provide evidence of cointegration among the variables. This gives strong evidence that the variables have long run equilibrium. The Fully Modified Ordinary Least Squares procedure developed by Pedroni is used to produce consistent estimates of the relevant panel variables in the cointegrated money demand function. Estimates for the entire sample period of 1998 to 2012 show that the demand for money responds negatively to variations in the interest rate and the expected rate of inflation in the long run. The interest rate proves to be statistically significant in the long run; the expected rate of inflation on the other hand is statistically insignificant in the long run.

The error correction models which represent the short run money demand function show that the interest rate is insignificant while the expected rate of inflation is statistically significant. This confirms the claim by some economists that the interest rate does not exert a significant influence on money demand as far as developing countries are concerned. The study shows that in the short run when substitutability between money and financial assets is limited, the appropriate opportunity cost variable in the money demand function is the expected rate of inflation. Although these findings differ from those of some other researchers, they can be explained by the fact that, with financial innovation in the long run, economic agents are likely to get access to more financial assets. This increases the substitution between money and financial assets and the interest rate becomes the appropriate opportunity cost variable in the money demand function for developing countries.

In conclusion, the demand for money should be regarded as being interest inelastic in the short run but interest elastic in the long run in developing economies. The study employs panel data techniques, with more efficient econometric estimates, and therefore contributes immensely to the theoretical literature of the demand for money in developing countries. An important policy implication that can be inferred from the results of this study is that fiscal policy rather than monetary policy should be utilised to stabilise the economies of developing countries. With money demand serving as an important aid to policy formulation, the study recommends continued research in money demand especially regarding issues of stability and volatility of money demand functions in developing countries.

\section{References}

Abdulkheir, A. Y. (2013). An Analytical Study of the Demand for Money in Saudi Arabia. International Journal of Economics and Finance, 5(4). https://doi.org/10.5539/ijef.v5n4p31

Abdullah, H., Ali, J., \& Matahir, H. (2010, July). Re-Examining the Demand for Money in Asean-5 Countries. Asian Social Science, 6(7). https://doi.org/10.5539/ass.v6n7p146

Arestis, \& Demetriades, P. O. (1991, September). Cointegration, Error Correction and the Demand for Money in Cyprus. Applied Economics, 23(9), 1417-24. https://doi.org/10.1080/00036849100000192

Arize, A. C., \& Nam, K. (2012). The Demand for Money in Asia: Some Further Evidence. International Journal of Economics and Finance, 4(8). https://doi.org/10.5539/ijef.v4n8p59 
Baharumshah, A. Z., Mohd, S. H., \& Masih, A. M. M. (2009). The Stability of Money Demand in China: Evidence from ARDL Model. Economic Systems, 33(3), 231-244. https://doi.org/10.1016/j.ecosys.2009.06.001

Bahmani, S. (2013). Exchange rate volatility and demand for money in less developed countries. Journal of Economics \& Finance, 37, 442-452. https://doi.org/10.1007/s12197-011-9190-y

Bahmani-Oskooee, M., \& Bahmani, S. (2015). Nonlinear ARDL Approach and the Demand for Money in Iran. Economics Bulletin, 35(1), 381-391.

Baumol, W. J. (1952). The Transactions Demand for Cash: An Inventory Theoretic Approach. Quarterly Journal of Economics, 66, 545-556. http://dx.doi.org/10.2307/1882104

Breitung, J. (2000). The Local Power of some Unit Root Tests for Panel Data. In B. Baltagi (Ed.), Advances in Econometrics: Non-stationary Panels, Panel Cointegration, and Dynamic Panels (pp. 161-178). Amsterdam, JAI Press. https://doi.org/10.1016/S0731-9053(00)15006-6

Carrera, C. (2008). Long-run Money Demand in Latin-American Countries: Nonestationary Panel Data Approach. Retrieved from http://www.williams.edu/cde/

Dagher, J. C., \& Kovanen, A. (2011, November). On the Stability of Money Demand in Ghana: A Bounds Testing Approach. IMF Working Paper No. 11/273.

Fisher, I. (1911). The Purchasing Power of Money (New York; Macmillan, 1911). PMCid: PMC2332238

Friedman, M. (1956). The Quantity Theory of Money: A Restatement. Studies in the Quantity Theory of Money, University of Chicago Press.

Gujarati, D. N. (2003). Basic Econometrics (4th ed.). Boston: McGraw Hill-Publishing.

Hadri, K. (1999). Testing the Null Hypothesis of Stationarity Against the Alternative of a Unit Root in Panel Data with Serially Correlated Errors. Manuscript, Department of Economics and Accounting, University of Liverpool.

Hamori, S. (2008). Empirical Analysis of the Money Demand Function in Sub-Saharan Africa. Economics Bulletin, 15, 1-15.

Harb, N. (2004). Money Demand Function: A Heterogeneous Panel Application. Applied Economics Letters, 11, 551-555. https://doi.org/10.1080/1350485042000225739

Herve, D. B. G., \& Shen, Y. (2011). The Demand for Money in Cote d'Ivoire: Evidence from the Cointegration Test. International Journal of Economics and Finance, 3(1).

Hossain, A. (2006). The Income and Interest Rate Elasticities of Demand for Money in Bangladesh: 1973-2003. The ICFAI Journal of Monetary Economics, 73-96.

Im K. S., Pesaran, M.H., \& Shin, Y. (2003). Testing for Unit Roots in Heterogeneous Panels. Journal of Econometrics, 115, 53-74. https://doi.org/10.1016/S0304-4076(03)00092-7

Kao, C., Chiang, M., \& Chen, B. (1999). International R\&D Spillovers: An Application of Estimation and Inference in Panel Cointegration. Oxford Bulletin of Economics and Statistics, 61(4), 691-709. https://doi.org/10.1111/1468-0084.61.s1.16

Keynes, J. M. (1936). The General Theory of Employment, Interest and Money. 7. JMK. (1936) London: Macmillan.

Kumar, S., Chowdhury, M., \& Rao, B. B. (2010). Demand for Money in the Selected OECD Countries: A Time Series Panel Data Approach and Structural Breaks. MPRA Paper No. 22204.

Kumar, S., Webber, D. J., \& Fargher, S. (2010, September). Money Demand Stability: A Case Study of Nigeria. Auckland University of Technology.

Laidler, D. E. W. (1985). The Demand for Money: Theories and Evidence (3rd ed.). New York: Dunn-Donnelley. PMCid:PMC499270.

Levin, A., \& Lin, C. F. (1993). Unit Root Tests in Panel Data: New Results. University of California, San Diego, Discussion Paper, No. 93-56.

Levin, A., Lin, C. F., \& Chu, C. J. S. (2002). Unit Root Tests in Panel Data: Asymptotic and Finite-Sample Properties. Journal of Econometrics, 108, 1-24. https://doi.org/10.1016/S0304-4076(01)00098-7

Marshall, A. (1923). Money, Credit and Commerce. London: Macmillan. 
Narayan, P. K., Narayan, S., \& Mishra, V. (2009). Estimating Money Demand Functions for South Asian countries. Empirical Economics, 36(3), 685-696. https://doi.org/10.1007/s00181-008-0219-9

Pathak, D. S. (1981). Demand for Money in a Developing Country: An Econometric Study. Indian Economic Journal, 29, 10-16.

Pedroni, P. (1999). Critical Values for Cointegration Tests in Heterogeneous Panels with Multiple Regressors. Oxford Bulletin of Economics and Statistics, 61, 653-670. https://doi.org/10.1111/1468-0084.61.s1.14

Phillips, P. C. B., \& Moon, H. R. (1999). Linear Regression Limit Theory for Nonstationary Panel Data. Econometrica, 67, 1057-1111. https://doi.org/10.1111/1468-0262.00070

Phillips, P. C. B., \& Moon, H. R. (2000). Nonstationary Panel Data Analysis: An Overview of some Recent Development. Econometric Reviews, 19, 263-286. https://doi.org/10.1080/07474930008800473

Pigou, A. C. (1917, November). The Value of Money. The Quarterly Journal of Economics, 37, 38-65. https://doi.org/10.2307/1885078

Rao, B. B., \& Kumar, S. (2007, November). Cointegration, Structural Breaks and the Demand for Money in Bangladesh. MPRA Paper No. 1546.

Rao, B. B., \& Kumar, S. (2009). A Panel Data Approach to the Demand for Money and the Effects of Financial Reforms in the Asian Countries. Economic Modelling, Elsevier. https://doi.org/10.1016/j.econmod.2009.03.008

Rao, B. B., \& Kumar, S. (2010). Error-Correction Based Panel Estimates of the Demand for Money of Selected Asian Countries with the Extreme Bounds Analysis. MPRA Paper No. 27263.

Rao, B. B., \& Singh R. (2005). Demand for money in India: 1953-2003. Applied Economics, 38, 1319-1326.

Sichei, M. M., \& Kamau, A. W. (2012). Demand for Money: Implications for the Conduct of Monetary Policy in Kenya. International Journal of Economics and Finance, 4(8). https://doi.org/10.5539/ijef.v4n8p72

Simmons, R. (1992). An Error-correction Approach to Demand for Money in Five African Developing Countries. Journal of Economic Studies, 19(1), 29-47. https://doi.org/10.1108/01443589210015935

Singh, R., \& Kumar, S. (2012). Application Of The Alternative Techniques to Estimate Demand for Money in Developing Countries. The Journal of Developing Areas, 46(2), 43-63. https://doi.org/10.1353/jda.2012.0036

Suliman, S. Z., \& Dafaalla, H. A. (2011). An econometric analysis of money demand function in Sudan, 1960 to 2010. Journal of Economics and International Finance, 3(16), 793-800. https://doi.org/10.5897/JEIF11.122

Tang, C. F. (2009). How Stable is the Demand for Money in Malaysia? New Empirical Evidence from Rolling Regression. IUP Journal of Monetary Economics.

Terriba, O. (1973). The Demand for Money in Nigeria. Economic Bulletin of Ghana, 3, 14-22.

Tobin, J. (1956). The Interest Elasticity of Transactions Demand for Cash. The Review of Economics and Statistics, 38, 241-47. https://doi.org/10.2307/1925776

Tobin, J. (1958). Liquidity Preference as Behaviour Towards Risk. The Review of Economics Studies, 25(67), 65-86. https://doi.org/10.2307/2296205

Valadkhani, A. (2008). Long and Short Run Determinants of the Demand for Money in the Asian-Pacific Countries: An Empirical Panel Investigation. Annals of Economics and Finance, 9, 77-90.

Wong, C. H. (1977). Demand for Money in Developing Countries: Some Theoretical and Empirical Results. Journal of Monetary Economics, 3(1), 59-86. https://doi.org/10.1016/0304-3932(77)90005-8

\section{Copyrights}

Copyright for this article is retained by the author(s), with first publication rights granted to the journal.

This is an open-access article distributed under the terms and conditions of the Creative Commons Attribution license (http://creativecommons.org/licenses/by/4.0/). 